\title{
Czyn i osoba w akcie normatywnym, czyli co znaczy zwrot ma prawo w Konstytucji III Rzeczypospolitej
}

\section{An Act and Person in a Statutory Instrument - the Meaning of a Syntagm "to Have a Right" under the Constitution of the Republic of Poland}

\author{
Maria Teresa Lizisowa \\ UL. DOBREgO PASTERZA 29/24 \\ 31-416 KRAKÓW \\ Streszczenie
}

Problem badawczy sformułowany $\mathrm{w}$ temacie artykułu dotyczy związków między treścią zawartą $\mathrm{w}$ przepisach a formą wypowiedzi. Przedmiotem analizy jest semantyka czasownika modalnego w zdaniach normatywnych. W artykule przedstawiono, jak w struktury języka aktu ustawodawczego są wpisane filozofia prawa, ideologiczne założenia ustawodawcze i tradycja polskiego języka prawnego.

Słowa klucze: język prawny, konstytucja, predykat modalny, zaimek określający

1. Prawo podmiotowe a możność działania. Teoretyczny aspekt prawa od wieków jest przedmiotem dociekań klasycznych nurtów prawoznawstwa: nauki o prawie naturalnym, pozytywizmu prawniczego i realizmu prawniczego. Nowożytna filozofia prawa natury wiązała nierozłącznie $\mathrm{z}$ naturą człowieka niezbywalne prawa podmiotowe. Wzorce postępowania $\mathrm{w}$ zakresie powinności czyniła miarą osądów moralnych działalności ludzkiej. Rolę stróża tych praw w ramach umowy społecznej przypisywała państwu ${ }^{1}$. Zwrot językowy w naukach humanistycznych XIX i XX wieku ukierunkował prawoznawstwo $\mathrm{w}$ stronę badań struktury języka prawnego oraz syntaktyki, semantyki i pragmatyki języka prawnego jako rejestru języka etnicznego ${ }^{2}$.

Prawo w znaczeniu najogólniejszym zdefiniował Leon Zawadowski jako „kategorialny stan rzeczy”, który istnieje niezależnie od podmiotu poznającego, ale może być przez ten podmiot odkryte i wyrażone w zdaniu komunikującym. Wieloznaczność wypowiedzi dotyczy nie terminu prawo, lecz wynika z różnorodności stanów rzeczy³. Czesław Znamierowski twierdzil, że gdy intencja czynu zwraca się ku drugiej osobie, będącej recypientem działania, działanie jest interpersonalne. Równowaga czynu oparta na normie ustanawia poczucie

${ }^{1}$ Zob. według filozofii Johna Locka (1632-1704): Tokarczyk 2004: 117.

${ }^{2}$ Zob. prawo jako zjawisko językowe: Zirk-Sadowski 2000: 95-110.

3 Zob. Zawadowski 1966: 281 i n. 
powinności w stosunku do otoczenia. Warunki i czyn projektowany na określonym tle ogólnym środowiska milcząco przyjmujemy za tak niezmienne, że je pomijamy $\mathrm{w}$ wysłowieniu normy, także $\mathrm{w}$ tetycznym obszarze działania jako powinności wykonania czynu w warunkach zastosowania normy. Ostatecznie norma jest wyrazem osiągniętej drogą stanowienia

równowagi pomiędzy człowiekiem i jego otoczeniem. W społecznym stanowieniu, w warunkach władzy, umożliwienie czynu jednej osoby przekształca stan równowagi, jest działaniem z cudzej mocy, a sprawca działania jest swoiście wyznaczony lub przydzielony4.

Językowe ujęcie sensu wyrażenia prawo jest najbliższe koncepcji prawa naturalnego, gdzie przez prawo najogólniej rozumie się prawidłowość, wyrażającą się $\mathrm{w}$ obiektywnym porządku rzeczy związanym $\mathrm{z}$ działaniem i celem. Prawidłowość dotyczy zarówno faktu, jak i relacji do rzeczy. W książce Człowiek $i$ prawo naturalne Mieczysław Albert Krąpiec pisze, że:

„[...] zwłaszcza działanie regularne i konieczne, jest zawsze działaniem uprzedmiotowionym, działaniem względem (w stosunku do) czegoś kogoś. W samo zatem działanie, jako łączące podmiot działający z przedmiotem, jest już wpisana relacja jako byt międ zy. Nie znaczy to, że samo działanie jest relacją, lecz znaczy to, że wszelkie działanie (a zwłaszcza działanie naturalne) powoduje relację między podmiotem a przedmiotem"5.

Z tego wnioskuje, że w działaniu naturalnym i regularnym objawia się prawo jako stała relacja działającego podmiotu, a jeżeli „owo ukierunkowanie działania przebiega zgodnie $\mathrm{z}$ naturą bytu działającego oraz bytu będącego przedmiotem działania, mówimy wówczas, że byt działa „prawidłowo", zg o dni e z prawem" 6 . Tak rozumiane prawo realizuje się w warunkach ludzkiej egzystencji jako fakt prawa lub jako prawo podmiotowe osoby.

Nasze rozważania dotyczyć będą prawa podmiotowego, rozumianego (za Krąpcem) jako moralna możność czynienia czegoś w przyporządkowaniu do osoby drugiej. Wobec tego przyjmujemy, że prawo jawi się jako korelat powinności. Krąpiec podkreśla, że prawo gwarantuje dobro interpersonalne w tym sensie, że w działaniu lub niedziałaniu jednej osoby nie będzie uszczuplone dobro innych osób, których to działanie dotyczy. Debitum uczynku w aspekcie prawnym, wyrażone sprzężonymi terminami należność — powinność, gwarantuje porządek prawny przy założeniu: „To bowiem, co jednej osobie jako korelatowi relacji prawnej się należy, to zarazem osoba druga powinn a uczynić”.

\footnotetext{
4 Zob. o równowadze czynu w stanowieniu norm: Znamierowski 1947/1948: 23-27 i 65; 235-239.

5 Zob. Krąpiec 1993: 21-22.

${ }^{6}$ Zob. Krąpiec 1993: 22. Autor akceptuje koncepcje prawa jako ogółu norm spajających organizację społeczną, które jednak nie wyjaśniają do końca tego, czym jest prawo, bowiem dotyczą tylko stosunku osoby prawnej. Wstępne definicje prawa, według Krąbca to: „a) relacja człowieka do rzeczy, którą dysponuje lub która leży w zasięgu jego dyspozycji; b) moralna możność czynienia lub posiadania czegoś; c) zespół norm lub reguł prawnych; d) nauka prawa. Sensy a) i b) to prawo jako relacja i jako moralna możność odnoszą się do prawa podmiotowego (ius subiectivum), sensy c) i d) odnoszą się do prawa obiektywnego norm i nauki (ius obiectivum).

7 Zob. Krąpiec 1993: 25.
} 
2. Semantyczna wartość zwrotu ma prawo. Prawoznawcza kwalifikacja zwrotu ma prawo w podręczniku do teorii prawa wyznacza trzy odcienie znaczeniowe tego wykładnika modalnego: wolność, uprawnienie i kompetencję. Desygnatem przedmiotowym prawa podmiotowego jest sytuacja prawna osoby posiadającej to prawo. Sytuacja ta dotyczy kwalifikowanych przez normę własnych czynów posiadającego prawo, dotyczy czynności innej osoby (recypienta) odnoszących się do spraw posiadającego prawo, a w normach kompetencyjnych przedmiotem prawa podmiotowego są czynności konwencjonalne posiadającego prawo ${ }^{8}$. Maciej Zieliński zwraca uwagę na dyrektywne rozumienie zwrotu ma prawo ${ }^{9}$, którego niejednoznaczość precyzuje kontekst językowy $\mathrm{w}$ tekstach ustawodawczych wsparty generalnym założeniem normatywności ${ }^{10}$.

Zwrot ma prawo jest predykatem o charakterze posesywnym, oznacza czyjeś prawo $\mathrm{w}$ tym sensie, że wyraża immanentnie związek $\mathrm{z}$ zaimkiem $\mathrm{w}$ funkcji deiktycznej, albo rzeczownikiem relacyjnym lub też $\mathrm{z}$ grupą imienną $\mathrm{w}$ funkcji deskryptywnej. Posesywność immanentna jest nieoddzielona od niby-właściciela ${ }^{11}$. Tworzy spójną grupę syntaktyczną, w której członem wskazującym jest podmiot zdania, a członem znaczącym jest dopełnienie prawo, pozostające w różnych relacjach do podmiotu. Dopełnienie to jest logicznie i semantycznie tematem wypowiedzi. Czasownik mieć w języku prawnym, podobnie jak w polszczyźnie ogólnej, jest wieloznaczny; problemem semantycznym jest też, czy jest wyrażeniem elementarnym, czy wtórnym obok zastępowanych w praktyce redakcyjnej może, ma uprawnienie, ma roszczenie, może żądać, może korzystać z prawa i innymi ${ }^{12}$. Zwrot ma prawo jest wykładnikiem modalnym zdania normatywnego ${ }^{13}$. Jest to jednak raczej zwrot potoczny, tak obecnie, jak i w historii języka polskiego.

Najstarsze zabytki piśmiennictwa z XV wieku notują modalny predykat ma prawo $\mathrm{w}$ rotach przysiąg sądowych. Zwrot ten był formułą stwierdzającą kompetencję do wytoczenia powództwa (ma prawo) w opozycji do zaprzeczenia powództwa (daje

${ }^{8}$ Informację tę podaję za podręcznikiem: Redelbach, Wronkowska, Ziembiński 1993: 150.

9 Rozróżnienie dekryptywnego i dyrektywnego poziomu interpretacji tekstu prawnego, zob.

Sarkowicz 1995.

${ }^{10}$ Zob. rola czasowników normatywnych: Zieliński 2002: 154 - 162.

${ }^{11} \mathrm{O}$ rodzajach posesywności według Kazimierza Polańskiego, zob. EWJP 261-262.

12 Zob. Zaron

${ }_{13}$ Czyny podlegają kwalifikacji prawnej jako obowiązujące (powinne). W językoznawstwie mówi się tu o modalności w znaczeniu powinnościowym - stwierdzającym istnienie obowiązku, wydanie zakazu czy pozwolenia. Modalność powinnościowa (deontyczna) w naukach o języku definiowana jest jako „stosunek sprawcy akcji do jej realizacji, jako stosunek podmiotu — agensa albo pacjensa do akcji nazwanej czasownikiem"13. Według Johna Lyonsa konieczność deontyczna wiąże się z logiką obowiązku i zezwolenia. Dotyczy „konieczności lub możliwości aktu dokonywanego przez osobę moralnie odpowiedzialną" ${ }^{13}$. W prawoznawstwie mianem modalności podstawowych określa się kwalifikacje „zachowania odnoszonego do adresata normy jako zakazanego, nakazanego, indyferentnego, dozwolonego, fakultatywnego czy będącego przedmiotem czyjegoś obowiązku”. Do modalności pochodnych zalicza się „kwalifikację zachowań jako będących przedmiotem uprawnienia, kompetencji czy wolności prawnie chronionej" z pozycji innej osoby niż adresat normy ${ }^{13}$. Co do treści językoznawcze i prawnicze definicje modalności są zbieżne, chociaż w tych definicjach mówi się różnymi językami: agens to adresat normy: sprawca, wykonawca czynności, osoba działająca według dyspozycji normy - pacjens to inna osoba niż adresat normy, odbiorca czynności agensa, nazwanej przez orzeczenie przechodnie. 
winę) $^{14}$. Nie był używany jednak w tekstach ustawodawczych (statutach). Nie występuje też $\mathrm{w}$ słowniku polszczyzny XVI wieku w znaczeniu prawnym $\mathrm{w}$ zwrotach decyzyjnych, potwierdza się natomiast jego używanie $w$ praktyce sądowej. XVIII-wieczny słownik Lindego notuje tylko zwroty potoczne: nie masz do mnie prawa oraz śmierć ma prawo $i$ na nas $i$ na wszystkie rzeczy ${ }^{15}$. W dyspozycji ustawodawcy nie został też poświadczony w Statutach litewskich, ani w Zbiorze praw sqdowych Andrzeja Zamoyskiego, ani w Konstytucji 3 Maja. Pojawia się dopiero w Konstytucji Księstwa Warszawskiego (1 raz — prawo do głosowania), w Konstytucji Królestwa Polskiego (4 razy — w odniesieniu do króla i członków senatu). W odniesieniu do obywateli występuje w Konstytucji marcowej (14 razy), w Konstytucji kwietniowej (7 razy) i w Konstytucji PRL (5 razy).

Sytuacja prawna osoby, która „ma prawo” ze względu na rozważaną normę lub zespół norm w danym systemie prawnym jest na tyle skomplikowana, że zwrot ma prawo nie jest często używany w redakcji tekstów ustawodawczych. Zwykle pojawia się, zdaniem prawników, słowo może (także z negacją), który w kontekście czynności konwencjonalnej podmiotowi normy przyznaje kompetencję - i to jest podstawowe znaczenie tego słowa w tekstach prawnych ${ }^{16}$. Tym bardziej zastanawia fakt, że w Konstytucji Rzeczypospolitej Polskiej z dnia 2 kwietnia 1997 r. ${ }^{17}$ aż 38 razy pojawia się zwrot ma prawo w różnych znaczeniach i konfiguracjach redakcyjnych.

3. Relacje osobowe. Reguły języka prawnego, charakterystyczne ze względu na leksykę profesjonalną i normatywność zdań, służą scalaniu wiedzy i takiemu rozkładaniu informacji, żeby w stopniu możliwie jednoznacznym identyfikować osoby i kwalifikować ich czyny. Wskazywanie i nazywanie podmiotów prawnych, adresata i recypienta, wiąże inne wyrażenia komunikatu, wskazując na dwustronny charakter normy prawnej, obejmującej skorelowane należności i powinności. Sytuacja wypowiedzi nie obejmuje konkretnego interlokutora. Wyrażenia deiktyczne i nominalne stanowią indeksalne znaki osób nie jako pojedynczych przedmiotów, lecz ich klas. Wskazywanie na adresata, a także puszczenie adresata, jest nie tylko regulowane zasadami techniki prawodawczej, nie tylko zależy od rozczłonkowania syntaktycznego i treściowego oraz kondensacji norm sprzężonych, lecz także sprawia trudności przekładowe ze względu na znaczenie tekstu (Jopek-Bosiacka 2006: 25-43).

W treść przekazu zawartą w ramie metatekstowej, która jak wiadomo przypisana jest gatunkowi tekstu, jest wbudowana kategoria nadawcy. Rama ta nadaje wypowiedzi charakter subjunktywny. Status nadawcy organizuje wypowiedź normatywną przez wskazanie adresata, recypienta i przedmiotu normowania. Toteż predykaty zdań normatywnych są trójelementowe. Jeżeli w danym przepisie te elementy są wyzerowane, to presupozycje wyzerowanych elementów odsyłają do kontekstu danego aktu ustawodawczego, do obowiązującego systemu norm lub do wiedzy

14 W polszczyźnie historycznej posesywnej strukturze (X ma prawo) można było wymieniać użyte składniki (X jest praw). Jako co mi dała Dzierska winę o dwie skrzyni... tegom nie miał prawa z nią dzielić Słstpol. VII 44, por. Iże w czem Wirzchosław Maćka winował, w tem jest Maciek praw Słstpol. VII 49.

15 Linde IV 462.

16 Zob. Zieliński 2002: 160-161. Autor jest zwolennikiem unikania zwrotu ma prawo w tekstach ustawodawczych („bo po co mnożyć byty nad konieczność”).

17 Podstawą analizy jest tekst ogłoszony w Dz. U. 1997 nr 78 poz. 438. Tekst ujednolicony. 
uczestników komunikacji językowej — nadawcy i odbiorcy tekstu. Wyznaczony lub przydzielony sprawca czynności ma $\mathrm{w}$ wypowiedzi prawnej przydzielone także działanie konieczne. To działanie jest przedmiotem stanowienia jako relacja działającego podmiotu w przyporządkowaniu do drugiej osoby.

Słowo każdy to zaimek określający, który wskazuje na kompletność danego zbioru elementów dystrybutywnie, poprzez wskazanie na elementy zbioru (każdy człowiek), lecz nie oznacza bezwyjątkowości. Zaimek wszyscy określa natomiast kompletność danego zbioru kolektywnie, wskazując na zbiór jako całość18. Zwraca uwagę w tekście Konstytucji także użycie zaimka każdy w funkcji uogólniającej kwantyfikację np. każda ze stron, mimo że pominięcie zaimka i tak w polskiej kulturze redagowania i interpretacji tekstów prawnych istnieje zasada odnoszenia nazwy pospolitej do każdego z jej desygnatów ${ }^{19}$.

Argumenty osobowe są wyrażeniami niedookreślonymi i nieostrymi. Nieostrość językowa polega na tym, że treść słownikowa wyrażenia nie stanowi zespołu konstytutywnego cech desygnatu. Takimi wyrażeniami są zarówno zaimki każdy, wszyscy, jak i deskrypcje proste, np. obywatel, sędzia, rodzina, czy złożone, np. organy państwa. Toteż w przepisach normujących pewne sytuacje osób używane są wyrażenia zawężające pas nieostrości, np. dziecko pozbawione opieki rodziców; obywatel polski; każdy, czyje konstytucyjne wolności lub prawa zostaty naruszone. Nieostre są także zwroty szacunkowe, np. do równego traktowania, do sprawiedliwego i jawnego rozpatrzenia sprawy. Desygnatem tych zwrotów są oceny akceptowane społecznie, lecz zwroty te nie wyrażają ocen, przedmiotem stanowienia jest tylko klauzula generalna) ${ }^{20}$.

4. Zwrot ma prawo w jednostkach redakcyjnych Konstytucji. Dyskurs konstytucyjny charakteryzuje się tym, że jest pisemnym rezultatem czynności legislacyjnych organów władzy publicznej. Dla zwykłych obywateli i instytucji formuluje normy prawne zagwarantowane przymusem obowiązywania. Formuly języka mają postać dyrektywy obowiązywania w odniesieniu do zwykłych czynności psychofizycznych lub do czynności konwencjonalnych ${ }^{21}$. Z dynamicznego ujęcia prawa podmiotowego wynika, że zwrot ma prawo zobowiązuje podmioty prawne do działania. Działanie to jest przedmiotem normowania $w$ relacjach interpersonalnych, a moralnym kryterium prawa podmiotowego są współrzędne mu obowiązki.

Stanowienie norm prawnych, wiąże osoby, zdarzenia, sytuacje i przedmioty $\mathrm{w}$ aspekcie illokucyjnym i perlokucyjnym aktu mowy. Zwrot ma prawo, będąc wykładnikiem modalności w zdaniu normatywnym, kwalifikuje sytuację prawną podmiotów działających. Odpowiednie formy języka prawnego służą wyrażaniu dyspozycji: komu przysługuje prawo podmiotowe, kto zgodnie z normą jest obowiązany wykonać czynność podlegającą normowaniu i jakie działania podmiotów normy prawnej są czynnością podlegającą normowaniu. Formy języka

\footnotetext{
${ }^{18}$ Zob. Roman Laskowski, hasło morfologia. (Encyklopedia językoznawstwa ogólnego)

19 Zob. Zieliński 2002: 147.

${ }^{20} \mathrm{O}$ zwrotach niedookreślonych i nieostrych w tekście prawnym, zob. Zieliński 2002: 163-171.

${ }^{21}$ Charakterystyka i klasyfikacja norm według: Zieliński 2002: 26-41. Kompetencja, według autora, zwykle łączy się z obowiązkiem skorzystania z niej.
} 
to odpowiednie połączenie wyrazów w minikontekście zdania, w mediakontekście jednostki systematyzacyjnej i w makrokontekście całego aktu prawnego ${ }^{22}$.

4.1. Formuła składniowa: $X$ ma prawo do czynienia $C$ przez $Y$ służą do sformułowania dyspozycji, w której przedmiotem normowania jest czynność recypienta działania nakazanego przez normę na rzecz adresata wypowiedzi:

Art. 32. 1. Wszyscy mają prawo do równego traktowania przez władze publiczne.

Art. 45.1. Każdy ma prawo do sprawiedliwego i jawnego rozpatrzenia sprawy ... przez... niezawisły sąd.

Art. 71.1. Rodziny znajdujące się w trudnej sytuacji materialnej i społecznej... mają prawo do szczególnej

pomocy ze strony władz publicznych.

Art. 71.2. Matka... ma prawo do szczególnej pomocy ze strony władz publicznych.

Art. 72. 2. Dziecko pozbawione opieki rodzicielskiej ma prawo do opieki i pomocy władz publicznych.

Pragmatyczna analiza przytoczonych zdań jest następująca: aspekt illokucyjny aktu stanowienia kierowany jest do adresata (uogólnionego: rodziny, matka, dziecko lub wskazanego wszyscy, każdy), aspekt perlokucyjny — do recypienta (władze publiczne, sąd). Zatem przepisy Konstytucji nadają adresatowi upoważnienie do zaktualizowania czynności opiekuńczej przez organy państwa na jego rzecz. Są to konstrukcje kauzatywno-modalne, w których orzeczenie ma prawo oznacza kompetencję pierwszego agensa (wszyscy, każdy, dziecko) do wywierania wpływu na czynność (równe traktowanie, rozpatrzenie sprawy, opieka i pomoc) innego agensa (władze publiczne, sąd). Wywieranie wpływu jest przedmiotem relacji między podmiotami. Mieć prawo do czynienia czegoś przez inną osobę jest wiec należnością - korelatem powinności, gwarantuje dobro interpersonalne gwarantuje, że dobro pierwszego agensa będzie uwzględnione w czynie drugiego agensa. W presupozycji pozostaje nakaz stworzenia przez państwo zabezpieczeń instytucjonalnych zapewniających prawa osobiste. Generalna zasada opozycji pomiędzy należnością jednego podmiotu normy a powinnością drugiego jest utrzymana we wszystkich przepisach konstytucyjnych ze zwrotem ma prawo, mimo nadania jej w redakcji tekstu różnych odcieni znaczeniowych.

4. 2. Formuły składniowe: $\mathrm{X}$ ma prawo czynić $\mathrm{C}$ w związku z czynem $\mathrm{C}_{1}$ dokonanym przez Y, służą do formułowania norm warunkujących negację cudzego postępowania

Art. 63. Każdy ma prawo składać petycje... do organów władzy publicznej... w związku z wykonywanymi przez nie zadaniami...

Predykat modalny ma prawo określa zakres normowania do sytuacji, w których orzeka się indyferencję postępowania adresata. Zdanie wyraża zezwolenie na podważenie decyzji organów władzy publicznej.

4. 3. Formuła składniowa: $\mathrm{X}$ ma prawo do żądania czynu $\mathrm{C}$ od $\mathrm{Y}$, jest schematem tekstowym normy warunkowanej przez cudze zachowanie się niezgodne z prawem,

22 Przyjmuję, że w zasadach redakcji i dekodowania tekstów prawnych wyróżnia się trzy rodzaje kontekstów: minikontekst — obejmujący sąsiedztwo wyrazów i zdań na zasadzie tematycznorematycznej; mediakontekst — ujmujący dany wyraz w obrębie wyższej jednostki systematyzacyjnej, jak rozdział wraz z tytułem; makrokontekst ujmujący dany wyraz w obrębie całego aktu prawnego wraz z tytułem, zob. Zieliński 2002: 145. 
która daje przyzwolenie na pociągnięcie do odpowiedzialności organy władzy publicznej za czyny niedozwolone ustawowo.

Art. 51. Każdy ma prawo do żądania sprostowania... informacji nieprawdziwych... zebranych w sposób sprzeczny z ustawą.

Art. 72. Każdy ma prawo żądać od organów władzy publicznej ochrony dziecka przed przemocą...

Art. 78. Każda ze stron ma prawo do zaskarżania orzeczeń i decyzji wydanych w pierwszej instancji.

Art. 79.1. Każdy, czyje konstytucyjne wolności lub prawa zostały naruszone, ma prawo, na zasadach określonych $\mathrm{w}$ ustawie, wnieść skargę do Trybunału Konstytucyjnego w sprawie zgodności z Konstytucją ustawy lub innego aktu normatywnego, na podstawie którego sąd lub organ administracji publicznej orzekł ostatecznie o jego wolnościach lub prawach albo o jego obowiązkach określonych w Konstytucji.

Art. 80. Każdy ma prawo wystąpienia... do Rzecznika Praw Obywatelskich z wnioskiem o pomoc w ochronie swoich wolności i praw naruszonych przez organy władzy publicznej

W podtytule II. rozdziału Konstytucji przepisy te zaliczono do „środków ochrony wolności i praw”. Za pomoca zwrotu ma prawo orzeka się o wywieraniu wpływu przez pierwszego agensa (działającego w imieniu własnym lub innej osoby) na czynność, którą ma obowiązek wykonać drugi agens, zabezpieczając dobro pierwszego agensa lub innej osoby, przed zakazanym czynem trzeciego agensa.

Art. 72.1. Rzeczpospolita Polska zapewnia ochronę praw dziecka. Każdy ma prawo żądać od organów władzy publicznej ochrony dziecka przed przemocą, okrucieństwem, wyzyskiem i demoralizacją.

4. 4. $\mathrm{W}$ formule składniowej $\mathrm{X}$ ma prawo do czego ustanawia się zapewnienie, że adresat wypowiedzi posiada globalne kompetencje do czynności nie zakazanej w systemie prawnym

Art.. 47. Każdy ma prawo do ochrony życia prywatnego...

Art. 64. 1. Każdy ma prawo do własności, innych praw majątkowych oraz prawo dziedziczenia.

.2. Własność, inne prawa majątkowe oraz prawo dziedziczenia podlegają równej dla wszystkich ochronie prawnej.

Art. 70. 1. Każdy ma prawo do nauki.

Art. 66.1. Każdy ma prawo do bezpiecznych i higienicznych warunków pracy.

2. Pracownik ma prawo do określonych $w$ ustawie dni wolnych od pracy i corocznych płatnych urlopów

Prawo podmiotowe, które ma oparcie $\mathrm{w}$ aktach prawa stanowionego, określa granice uprawnienia $\mathrm{w}$ tym sensie, że wyznacza roszczenie przysługujące do świadczenia ustalonego w akcie normatywnym, a państwo ma obowiązek działań w celu zabezpieczenia realizacji i ochrony praw osobistych, politycznych oraz ekonomicznych, socjalnych i kulturowych wobec obywateli. Nakaz ten odczytać można z mediakontekstu:

Art. 68. 1. Każdy ma prawo do ochrony zdrowia. 
Art.68. 2. Obywatelom, niezależnie od ich sytuacji materialnej, władze publiczne zapewniają dostęp do opie

ki zdrowotnej finansowanej ze środków publicznych.

3. Władze publiczne są obowiązane do zapewnienia szczególnej opieki zdrowotnej dzieciom...

Art. 69. Osobom niepełnosprawnym władze publiczne udzielają, zgodnie z ustawą, pomocy w zabezpieczeniu

egzystencji, przysposobieniu do pracy oraz komunikacji społecznej (to też prawa i wolności.

Warunki i czyn projektowany zostały pominięte $\mathrm{w}$ wysłowieniu normy jako niezmienne $\mathrm{w}$ założeniu interwencjonizmu państwowego. Akcent logiczny wypowiedzi normatywnej pada na osiągnięcie drogą stanowienia równowagi pomiędzy adresatem normy a otoczeniem w jakim się znajduje.

4. 5. W schemacie składniowym :Coś ma prawo czynić X, przepisy Konstytucji nadają kompetencję do wykonania danej czynności konwencjonalnej instytucji państwa.

Art. 125. 2. Referendum ogólnokrajowe ma prawo zarządzić Sejm bezwzględną większością głosów...

Członem wyjściowym tego zdania jest nazwa przedmiotu stanowienia. Jeśli przyjmiemy, że naczelną zasadą jest psychologiczny aspekt szyku wyrazów w zdaniu, który stanowi główny szkielet konstrukcji zdania, a tej zasadzie jest podporządkowany szyk pozostałych członów zdania, to zauważymy, że szyk członów wyjściowego i rozwijającego uzewnętrznia wartościujący kontur zdania. Hierarchia elementów treściowych jest wpisana w kontekst i konsytuację artykułu, rozdziału i całego tekstu konstytucji, stanowiąc tło wyrażeń konotujących i konotowanych. Zmiana szyku przesuwa akcent zdaniowy na przedmiot stanowienia (referendum), dopełnienie Sejm konotuje bezpośrednio orzeczenie ma prawo. Lecz elementy tekstu, które informują o punkcie wyjściowym są uwikłane w kontekst pozazdaniowy, w którym zdanie drugie (Referendum ogólnokrajowa ma prawo zarządzić Sejm) występuje jako znak konotujący, a w jego w kontekście jest znak konotowany (desygnat: może być przeprowadzone referendum ogólnokrajowe). Znak konotowany oznacza uprawnienie (może) do przeprowadzenia referendum bez wskazania na agensa, gdyż to przepis Konstytucji zezwala na referendum w sprawach szczególnie ważnych:

Art. 125. 1. W sprawach szczególnie ważnych dla państwa może być przeprowadzone referendum ogólnokrajowe.

Zdanie drugie wyraża kompetencję w zawiązku z uprawnieniem, wyznacza organ kompetencyjny do zarządzenia referendum. Wartościujący walor zdania wiąże się z szykiem wyrazów, a szyk wyrazów zależy od tła, w które zdanie jest uwikłane: człon rozwijający jest znakiem punktu wyjściowego, uzyskuje eksponowaną pozycję na końcu zdania jako nosiciel dominanty treściowej.

4. 6. Formuła składniowa: X ma prawo do czynienia $C$ służą do sformułowania dyspozycji, w której przedmiotem normowania jest czynność adresata wypowiedzi: Art. 35. 2. Mniejszości narodowe mają prawo do tworzenia własnych instytucji edukacyjnych... 
Art. 42.2. Każdy, przeciw komu prowadzone jest postępowanie karne, ma prawo do obrony...

Art. 47. Każdy ma prawo do ochrony prawnej życia prywatnego...

Art. 48.1. Rodzice mają prawo do wychowania dzieci zgodnie $\mathrm{z}$ własnymi przekonaniami.

Art. 53. 3. Rodzice mają prawo do zapewnienia dzieciom wychowania i nauczania moralnego i religijnego

Art. 53.3. Rodzice mają prawo do zapewnienia dzieciom wychowania i nauczania moralnego i religijnego.

Art. 59. 2. Związki zawodowe... mają prawo do rokowań... oraz do zawierania układów zbiorowych pracy...;

Związkom zawodowym przysługuje prawo do organizowania strajków pracowniczych...

Art. 6o. Obywatele polscy korzystający w pełni z praw publicznych maja prawo dostępu do służby publicznej.

Art. 62. Obywatel polski ma prawo udziału w referendum oraz prawo wybierania Prezydenta Rzeczypospolitej.

Art. 168.Jednostki samorządu terytorialnego mają prawo ustalania wysokości podatków...

Art. 172. Jednostki samorządu terytorialnego mają prawo zrzeszania się.

Aspekt illokucyjny i zarazem perlokucyjny aktu stanowienia jest kierowany do określonych deskryptywnie osób fizycznych i prawnych (mniejszości narodowe, związki zawodowe, jednostki samorządu, obywatele polscy, rodzice, każdy przeciw komu jest prowadzone postępowanie karne). Predykat modalny ma prawo orzeka, że adresat normy posiada zezwolenie na indyferencję postępowania, które dotyczy jego własnych czynów. Czyny te są adresatowi „należne” ze względów społecznych, politycznych czy gospodarczych.

5. Zakres normowania prawa podmiotowego w zwrocie ma prawo. W preambule Konstytucji Rzeczypospolitej Polskiej prawa podmiotowe nazwano prawami obywatelskimi, a ustanowiona Konstytucja zdefiniowana została „jako prawo podstawowe dla państwa”. Konstytucyjne rozdzielenie wolności i praw człowieka zaznaczone zostało $\mathrm{w}$ preambule i powtórzone $\mathrm{w}$ tytule II rozdziału Konstytucji oraz w przepisach dotyczących zasad ogólnych. Równocześnie w tych miejscach tekstu jest mowa o obowiązkach człowieka i obywatela (sytuacja wyznaczona treścią tytułu) i o obowiązkach ochrony interesów obywateli przez państwo. Pierwszy artykuł tego rozdziału stanowi, że:

Art. 30. Przyrodzona i niezbywalna godność człowieka stanowi źródło wolności i praw człowieka i obywatela. Jest ona nienaruszalna, a jej poszanowanie i ochrona jest obowiązkiem władz publicznych.

„Prawa człowieka - pisze Wojciech Zakrzewski - to kwalifikowana postać praw i wolności jednostki [...]. Źródłem tak rozumianych praw człowieka nie jest państwo i tworzony przez nie określony system prawny, lecz prawo naturalne, zgonie z którym podstawą większości praw jednostki jest przyrodzona godność osoby 


\section{Investigationes Linguisticae, vol. XVII}

ludzkiej” 23 . Termin prawo podmiotowe ma, według autora, konotacje aksjologiczne. „Oznacza się nim podstawowe i pochodne sytuacje prawne obywateli (uprawnienia, kompetencje, itd.), w skład których wchodzi roszczenie prawne" 24. Autor przyjmuje, że trzy kategorie praw, fundamentalne wolności osobiste wolne od ingerencji państwa, prawa i wolności polityczne, zapewniają wpływ na wykonywanie władzy państwowej w warunkach demokracji oraz prawa społeczno-ekonomiczne i kulturalne gwarantowane z przyczyn ekonomicznych i ideologicznych w warunkach interwencjonizmu państwowego.

Regulację wolności i praw rozpatruje się, według konstytucjonalistów, w kontekście obowiązków powszechnych (przestrzegania prawa, ponoszenia świadczeń publicznych, dbałości o środowisko), a także obowiązków obywatelskich wierności Rzeczypospolitej, obrony Ojczyzny i troski o dobro wspólne. ${ }^{25}$. W pracach prawniczych nie rozdziela się pojęć prawa i wolności. Przyjmuje się ustalone w prawoznawstwie znaczenie terminów prawniczych

uprawnienie, kompetencja, wolność dwustronna, wolność prawnie chroniona czy roszczenie dla oddania znaczenia wieloznacznych zwrotów językowych odpowiadających tym pojęciom.

Analiza referencji zwrotu ma prawo w Konstytucji III Rzeczypospolitej wykazała, że jest podstawa do wyodrębnienia sensu tego zwrotu, badając opozycję należność - powinność w odniesieniu do działań adresata normy i recypienta. Predykat modalny ma prawo orzeka o prawie do działania, a więc o kompetencji adresata wypowiedzi. Przepisy Konstytucji zezwalają adresatowi na czyny indyferentne, skorelowane $\mathrm{z}$ czynami nakazanymi recypientom. Recypientami działania są organy państwa lub sam adresat. W pierwszym przypadku ustawa konstytucyjna stanowi dla adresata określone należności, a dla recypienta określone powinności. W drugim przypadku stanowienie kompetencji dla adresata rodzi dla niego także zezwolenie na własne działanie. Należności te aktualizują się jako upoważnienie do podejmowania czynu projektowanego w określonym środowisku przez osoby do działania wyznaczone i przydzielone z mocy ustawy.

\section{Bibliografia}

Jopek-Bosiacka Anna, 2006, Przekład prawny i sądowy, Warszawa: Wydawnictwo Naukowe PWN

Krąpiec Mieczysław Albert, 1993, Człowiek i prawo naturalne, wyd. 3 poprawione, Lublin: Redakcja Wydawnictw Katolickiego Uniwersytetu Lubelskiego

Lizisowa Maria Teresa, 2006, Tekst - kontekst - interpretacja. W poszukiwaniu semiotyczno-dyskursywnych wzorców konkretyzacji języka, Kraków: Collegium Columbinum

Lyons, John, 1989, Semantyka, t. 2, przekł. Adam Weinsberg, Warszawa: PWN

${ }_{23}$ Zob. Zakrzewski 2002: 154. Autor przyjmuje, że istnieje trzy kategorie praw: fundamentalne wolności osobiste wolne od ingerencji państwa, prawa i wolności polityczne zapewniajace wpływ na wykonywanie władzy państwowej w warunkach demokracji oraz prawa społeczn-ekonomiczne i kulturalne gwarantowane $\mathrm{z}$ przyczyn ekonomicznych i ideologicznych w warunkach interwencjonizmu państwowego

24 Zakrzewski 2002: 159.

25 Zob. Młynarska-Sobaczewska 2007: 78-99. Autorka twierdzi, że podział na prawa i wolności konstytucyjne ma charakter czysto konwencjonalny. Zob. podobnie Zakrzewski 2002: 169-174. 
Maria Teresa Lizisowa: Czyn i osoba w akcie normatywnym, czyli co znaczy zwrot ma prawo w Konstytucji III Rzeczypospolitej

Redelbach Andrzej, Wronkowska Sławomira, Ziembiński Zygmunt, 1993, Zarys teorii państwa i prawa, Warszawa: Wydawnictwo Naukowe PWN

Rytel Danuta, 1982, Leksykalne środki wyrażania modalności $w$ języku polskim $i$ czeskim, Wrocław, Zakład Narodowy im. Ossolińskich

Sarkowicz Ryszard 1995, Poziomowa interpretacja tekstu prawnego, Kraków: nakł. UJ

Tokarczyk Roman, 2004, Filozofia prawa, wyd. 9, Lublin 2004: Wydawnictwo Uniwersytetu Marii Curie-Skłodowskiej

Zawadowski Leon, 1966, Lingwistyczna teoria języka, Warszawa: PWN

Zieliński Maciej, 2002, Wykładnia prawa. Zasady. Reguły. Wskazówki, Warszawa: Wydawnictwo Prawnicze LexisNexis

Ziembiński Zygmunt, 1966, Logiczne podstawy prawoznawstwa. Wybrane zagadnienia, Warszawa: Wydawnictwa Prawnicze

Zirk-Sadowski Marek, 2000, Wprowadzenie do filozofii prawa, Warszawa: Kantor Wydawniczy Zakamycze

Znamierowski Czesław, 1947/1948, Prolegomena do nauki o państwie i prawie, Poznań: Księgarnia Zdzisława Gustowskiego 